\title{
SYNERGIC EFFECT OF BOVINE HAIR HYDROLYSATE AND SULFITED LIGNINS ON LEATHER
}

\section{RETANNING}

\author{
Vanessa MOREIRA ${ }^{1}$, Joana FERREIRA ${ }^{1}$, Vânia F.M. SILVA ${ }^{1 *}$, António CRISPIM ${ }^{1}$, L. CARITA ${ }^{2}$, T. CRUZ ${ }^{3}$, Filipe \\ CRISPIM ${ }^{2,3}$
}

${ }^{1} \mathrm{CIETI} /$ ISEP - Centre of Innovation on Engineering and Industrial Technology / IPP School of Engineering, Rua Dr. António

Bernardino de Almeida, 831, 4200-072, Porto, Portugal

${ }^{2} \mathrm{CTIC}$ - Technological Centre for Leather Industry, Alcanena, Portugal

${ }^{3}$ INDINOR - Indústrias Químicas, SA, Porto, Portugal

Received: 13.03 .2018

Accepted: 16.09 .2018

https://doi.org/10.24264/Ifj.18.3.9

\section{SYNERGIC EFFECT OF BOVINE HAIR HYDROLYSATE AND SULFITED LIGNINS ON LEATHER RETANNING}

ABSTRACT. The aim of this work was the study of bovine hair hydrolysate and sulfited lignins effect in leather retanning process. Bovine hair from hair-saving process was thermally digested in alkaline conditions and after $\mathrm{pH}$ adjustment and concentration, was tested as retanning agent. Physical-mechanical tests were applied to evaluate the tear strength and lastometer test (in order to evaluate the grain cracking), and leather behavior regarding softness, grain firmness, and color. The experiments showed that hair hydrolysate, sulfited lignins and its mixtures can be used as retanning agents with good results when compared with a dispersing agent and a synthetic tannin. The keratin hydrolysate was also tested as finishing agent against casein and showed that it is not a good alternative.

KEY WORDS: hair-saving, keratin, leather retanning, sulfited lignin

\section{EFECTUL SINERGIC AL HIDROLIZATULUI DIN PĂR DE BOVINE ȘI AL LIGNINEI SULFITATE LA RETĂBĂCIREA PIELII}

REZUMAT. Scopul acestei lucrări a fost studierea efectului hidrolizatului din păr de bovine și al ligninei sulfitate în procesul de retăbăcire a pielii. Părul de bovine din procesul de depărare a fost digerat termic în condiții alcaline și, după ajustarea pH-ului și concentrare, a fost testat ca agent de retăbăcire. S-au efectuat teste fizico-mecanice pentru a evalua rezistența la rupere și la crăparea feței și comportamentul pielii în ceea ce privește moliciunea, fermitatea și culoarea. Experimentele au arătat că părul hidrolizat, lignina sulfitată și amestecurile acestora pot fi utilizate ca agenți de retăbăcire cu rezultate bune în comparație cu un agent de dispersie și un tanin sintetic. Hidrolizatul de cheratină a fost, de asemenea, testat ca agent de finisare comparativ cu cazeina și s-a demonstrat că nu este o alternativă bună.

CUVINTE CHEIE: valorificarea părului, cheratină, retăbăcirea pieilor, lignină sulfitată

\section{L'EFFET SYNERGIQUE DE L'HYDROLYSAT DE POILS DE BOVINS ET DE LA LIGNINE SULFITÉE SUR LE RETANNAGE DU CUIR}

RÉSUMÉ. Le but de cet article a été d'étudier l'effet de l'hydrolysat de poils de bovins et de la lignine sulfitée dans le processus de retannage du cuir. On a digéré thermiquement les poils de bovins provenant du procédé d'épilage des poils dans des conditions alcalines et, après ajustement du pH et concentration, on a testé l'agent de retannage. Des tests physico-mécaniques ont été appliqués pour évaluer la résistance à la déchirure et l'essai du lastomètre (afin d'évaluer le gerçure de la fleur), et le comportement du cuir en ce qui concerne la douceur, la fermeté et la couleur de la fleur. Les expériences ont montré que l'hydrolysat de poils, la lignine sulfitée et leurs mélanges peuvent être utilisés comme agents de retannage avec de bons résultats en comparaison avec un agent dispersant et un tanin synthétique. L'hydrolysat de kératine a également été testé comme agent de finition contre la caséine et on a montré que ce n'est pas une bonne alternative. MOTS CLÉS : récupération de poils, kératine, retannage du cuir, lignine sulfitée

* Correspondence to: Vânia F.M. SILVA, CIETI/ISEP - Centre of Innovation on Engineering and Industrial Technology/IPPS School of Engineering, Rua Dr. António Bernardino de Almeida, 831, 4200-072, Porto, Portugal, vfmsi@isep.ipp.pt. 


\section{INTRODUCTION}

Tanning process transforms animal hide into leather through a sequence of chemical, physical and mechanical operations including liming process. Liming process involves the removal of hair from epidermis of animal hide promoting swelling and preparing collagen and elastic fibers to be tanned.

This process, at industrial scale, is done with the application of alkali compounds such as calcium and sodium hydroxide, a reducing agent such as sodium sulfide or sodium sulfydrate, and some auxiliary chemicals [1]. Liming is normally done through the destruction of the hair fiber structure dissolving it in the bath. Another liming way is done with hair recovery preserving the hair fiber structure, usually known as the hairsaving liming process. Hair is mainly constituted by $95 \%$ keratin, being the other $5 \%$ non-keratin proteins [2]. Treatment and valorization of leather industry solid wastes is constantly developing, and the study of hair recovered in the hair-saving process is not an exception [3-5].

The pulp and paper industry produces sulfited lignins, which show a large field of applications. In the leather industry, this kind of substances could be used as dispersing and retanning agents. There are several types of sulfited lignins, depending on the raw material and type of process used in the pulp and paper production unity. One type of sulfited lignin particularly interesting to the tanning industry is the eucalypt origin, produced with magnesium sulfite [6].
Leather treatment comprises, among several processes and mechanical operations, the retannage process. This process is used to improve roundness, grain firmness and leather filling using vegetable tannins, syntans and various types of resins.

Research work has been published on the use of collagen hydrolysates obtained from chrome shavings and fleshings to develop products for leather retannage. Acrylic resins are used to prepare copolymers with collagen hydrolysates for leather retanning. Gluteraldehyde is also used to prepare copolymers with collagen hydrolysates for leather retanning [7-9].

In this work, the synergic effect of bovine hair hydrolysate and sulfited lignins is studied in the leather retanning process; hair hydrolysate was also tested as finishing agent against casein.

\section{EXPERIMENTAL}

\section{Materials and Methods}

\section{Hair Hydrolysate and Retanning Agents Preparation}

The hair used in this work was obtained from a hair-saving liming process described in Table 1 . This process was developed by CIETI and Curtumes Aveneda, a Portuguese tannery.

The process was made on small pieces of bovine salted hide, after a normal soak. The quantity of chemicals was calculated as the \% based on salted hide weight.

Table 1: Hair-saving Liming Process

\begin{tabular}{|c|c|c|c|c|}
\hline Chemical & Chemical Quantity (\%) & Time (min) & Temperature $(\stackrel{\circ}{ } \mathrm{C})$ & Control \\
\hline Water & 50 & \multirow{3}{*}{30} & \multirow{3}{*}{28} & \\
\hline Mazyme SDL (Amylase) & 0.3 & & & \\
\hline Borron DL (Lipase) & 0.15 & & & \\
\hline \multicolumn{5}{|c|}{ Add } \\
\hline Indical MS & 1 & \multirow{2}{*}{90} & \multirow{2}{*}{28} & \\
\hline $\begin{array}{l}\text { Erhavit DMC (Protease) } \\
\text { add }\end{array}$ & 0.3 & & & \\
\hline \multirow[t]{2}{*}{ Calcium Hydroxide } & 1 & 45 & 28 & \\
\hline & & \multicolumn{2}{|l|}{ Add } & \\
\hline Sodium Sulfide & 0.75 & 60 & \multirow[t]{2}{*}{28} & \multirow[t]{2}{*}{ Hair Removal } \\
\hline Sodium Sulfydrate & $\begin{array}{l}0.50 \\
\text { Remove the }\end{array}$ & ir by filtratio & & \\
\hline
\end{tabular}


Water

Calcium Hydroxide

Sodium Sulfide

Wash with Water
100

1

0.5

Run 10 min each hour overnight until 16 hours and drain

150
15

25

Drain and Flesh

The hair obtained from this process was firstly characterized for moisture, mineral and organic matter content, and protein content [10]. Then, hair was hydrolyzed according a process developed by ISEP: $100 \mathrm{~g}$ of hair were mixed with $500 \mathrm{~mL}$ of water and $10 \mathrm{~g}$ of sodium hydroxide and shaken in a thermostatic water bath at 85 ㅇ $\mathrm{C}$ for 24 hours. After hydrolysis, the mixture was filtered and the liquid phase, the hair hydrolysate, was adjusted to $\mathrm{pH} 6$ with hydrochloric acid and then concentrated by evaporation to about $35 \%$ of solids content. The final hydrolysate was designated as HK and characterized for moisture, mineral and organic matter content.

Then, different retanning agents were prepared by mixing hair hydrolysate and a sulfited lignin solution ( $50 \%$ conc.) for 30 minutes at room temperature, according to Table 2 .

Table 2: Retanning agents preparation

\begin{tabular}{ccc}
\hline Retanning Agent & $\begin{array}{c}\text { Hair Hydrolysate } \\
\text { Quantity (\%) }\end{array}$ & $\begin{array}{c}\text { Sulfited } \\
\text { Lignin Quantity } \\
(\%)\end{array}$ \\
\hline HK & 100 & 0 \\
HM & 0 & 100 \\
HMK20 & 20 & 80 \\
HMK40 & 40 & 60 \\
HMK50 & 50 & 50 \\
HMK60 & 60 & 40 \\
HMK80 & 80 & 20 \\
\hline
\end{tabular}

\section{Leather Retanning Trials}

The ability of the retanning agents prepared was evaluated by the retannage of small pieces of wet-blue from the backbone hide zone, previously shaved to a thickness of $1.6 \mathrm{~mm}$. The wet-blue shaved pieces, weighing approximately $100 \mathrm{~g}$, were submitted to a retanning, dyeing and fat-liquoring standard process varying only the retanning agent as shown in Table 3 for each trial done.

Table 3: Summary of retanning trials

\begin{tabular}{ccc}
\hline Retanning trial & Retanning Agent & Quantity used (\%) \\
\hline 1 & standard & 4 \\
2 & HK & 6 \\
3 & HM & 6 \\
4 & HMK20 & 6 \\
5 & HMK40 & 6 \\
6 & HMK50 & 6 \\
7 & HMK60 & 6 \\
8 & HMK80 & 6 \\
\hline
\end{tabular}

Chemicals used were all obtained from INDINOR, and the standard retanning agent was a mixture of $1 \%$ of Inditan RS (dispersing agent) and $3 \%$ of Inditan VOC (synthetic tannin). The trials were carried out using laboratory drums
(LFA-9293, Mathis), with temperature and speed control, and chemicals quantities were based on the weight of wet-blue hide pieces used. The standard process used is shown in Table 4. 
Table 4: Wet-blue Retanning, Dyeing and Fat-liquoring process

\begin{tabular}{|c|c|c|c|c|}
\hline Process & Chemical & Chemical Quantity (\%) & Time (min) & $\mathrm{T}(\underline{\mathrm{o}} \mathrm{C})$ \\
\hline Washing & Water & 300 & 10 & 35 \\
\hline \multicolumn{5}{|c|}{ Drain } \\
\hline & Water & 200 & & \\
\hline \multirow[t]{2}{*}{ Neutralization } & Sodium Formiate & 1.5 & 30 & 35 \\
\hline & Sodium Bicarbonate & 0.5 & & \\
\hline \multicolumn{5}{|c|}{$\mathrm{pH}$ control $(\approx 6)$ and drain } \\
\hline Washing & Water & 300 & 10 & 35 \\
\hline \multicolumn{5}{|c|}{ Drain } \\
\hline Retanning & $\begin{array}{l}\text { Water } \\
\text { Fortan A40 (acrylic resin) } \\
\text { Indinol EAF (sulfited oil) }\end{array}$ & $\begin{array}{l}50 \\
3 \\
2\end{array}$ & 15 & 30 \\
\hline \multicolumn{5}{|c|}{ 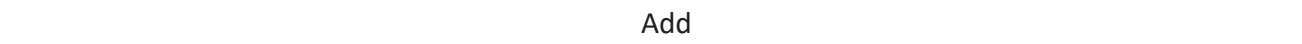 } \\
\hline Retanning & $\begin{array}{l}\text { Retanning Agent } \\
\text { Mimosa Vegetable Extract } \\
\text { Dyestuff }\end{array}$ & $\begin{array}{l}\mathbf{x} \\
3 \\
3\end{array}$ & 60 & 30 \\
\hline \multicolumn{5}{|c|}{ 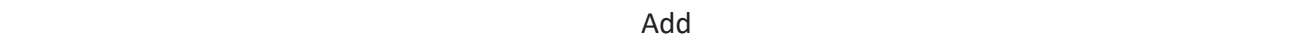 } \\
\hline Fixation & $\begin{array}{l}\text { Water } \\
\text { Formic Acid }\end{array}$ & $\begin{array}{c}100 \\
1\end{array}$ & 45 & 50 \\
\hline \multicolumn{5}{|c|}{$\mathrm{pH}$ control $(\approx 4)$ and drain } \\
\hline Dyeing & $\begin{array}{l}\text { Water } \\
\text { Dyestuff }\end{array}$ & $\begin{array}{l}150 \\
0.5\end{array}$ & 15 & 50 \\
\hline \multicolumn{5}{|c|}{ Add } \\
\hline Fat-liquoring & $\begin{array}{l}\text { Indinol BE (natural oil) } \\
\text { Indinol HS (synthetic oil) } \\
\text { Indinol EAF (sulfited oil) } \\
\text { Indinol LOX (lanolin based oil) }\end{array}$ & $\begin{array}{l}2 \\
3 \\
3 \\
4\end{array}$ & 60 & 50 \\
\hline \multicolumn{5}{|c|}{ Add } \\
\hline Fixation & Formic Acid & 0.5 & 30 & 50 \\
\hline \multicolumn{5}{|c|}{$\mathrm{pH}$ control $(\approx 3.8)$ and add } \\
\hline Washing & Water & 300 & 10 & 25 \\
\hline \multicolumn{5}{|c|}{ Squeeze, Dry and Stacked } \\
\hline
\end{tabular}

After this process the hide pieces were squeezed, dried and stacked. Properties, as physical-mechanical tests according to ISO 3377:2002 for tear strength, and ISO 3379:1976 for ball burst test (to evaluate the grain cracking), and leather behavior regarding softness and grain firmness, were evaluated for the different crust leather pieces obtained.

\section{Leather Finishing Trials}

Calf leather in crust stage was subjected to a finishing process. Four samples of A5 size were cut and named as I, II, III and IV.

Then, a Base Coat was applied with the components listed in Table 5. The dosage of this coat was $6 \mathrm{~g} / \mathrm{ft}^{2}$.

Table 5: Base Coat Components

\begin{tabular}{lc}
\hline \multicolumn{1}{c}{ Component } & Quantity (g) \\
Water & 620 \\
Polax S80 & 100 \\
$($ Wax) & \\
Telaflex A23 & 100 \\
$\begin{array}{l}\text { (Acrylic resin for impregnation } \\
\text { coats) }\end{array}$ & \\
$\begin{array}{l}\text { Telaflex U410 } \\
\text { (Polyurethane emulsion) }\end{array}$ & 100 \\
$\begin{array}{l}\text { Telafin Black } \\
\text { (pigment) }\end{array}$ & 80 \\
\hline
\end{tabular}


After the application of this base coat and the respective drying, all the four samples were pressed at $100^{\circ} \mathrm{C}, 1$ second and $100 \mathrm{kgf} / \mathrm{cm}^{2}$. The next step of the finishing process was to apply a Top Coat layer to each sample. The components of Top Coat are listed in Table 6. This composition was applied at $4 \mathrm{~g} / \mathrm{ft}^{2}$.

Table 6: Top Coat Components

\begin{tabular}{|c|c|c|c|c|}
\hline Component & $\begin{array}{c}\text { Sample } \\
\text { I } \\
(\mathrm{g}) \\
\end{array}$ & $\begin{array}{l}\text { Sample } \\
\text { II } \\
\text { (g) }\end{array}$ & $\begin{array}{l}\text { Sample } \\
\text { III } \\
\text { (g) }\end{array}$ & $\begin{array}{c}\text { Sample IV } \\
\text { (g) }\end{array}$ \\
\hline Water & 540 & 540 & 600 & 600 \\
\hline $\begin{array}{l}\text { Glanz F } \\
\text { (Mixture of Casein and } \\
\text { Albumin) }\end{array}$ & 400 & --- & 400 & --- \\
\hline $\begin{array}{l}\text { Keratin Hydrolysate } \\
\text { (Acrylic resin for impregnation } \\
\text { coats) }\end{array}$ & --- & 400 & --- & 400 \\
\hline $\begin{array}{l}\text { GW } 63 \\
\text { (Silicone emulsion) }\end{array}$ & 30 & 30 & --- & --- \\
\hline $\begin{array}{l}\text { Harter U } \\
\text { (Polyaziridine crosslinker) }\end{array}$ & 30 & 30 & --- & --- \\
\hline
\end{tabular}

After the application of these top coats and the respective drying, all the four samples were pressed at $110^{\circ} \mathrm{C}, 2$ second and $100 \mathrm{kgf} /$ $\mathrm{cm}^{2}$, and the colour fastness to rubbing (50 cycles) was tested according to ISO 11640.

\section{RESULTS AND DISCUSSIONS}

\section{Hair Hydrolysate and Retanning Agents Preparation}

The hair quantity obtained from the hairsaving liming process was $8.4 \mathrm{~g}$ from $100 \mathrm{~g}$ of salted hide, and its characterization is shown in Table 7.

Table 7: Bovine hair characterization

\begin{tabular}{lc}
\hline \multicolumn{1}{c}{ Parameter } & Result \\
\hline Moisture, (\%) & $67 \%$ \\
Organic Matter, (\% dry based) & $92 \%$ \\
Mineral Matter, (\% dry based) & $8 \%$ \\
N Kjeldahl (g N/100g sample) & $14.95 \mathrm{~g} \mathrm{~N} / \mathrm{g}$ sample \\
\hline
\end{tabular}

The final hair hydrolysate, obtained from the alkaline and thermal digestion, was characterized after $\mathrm{pH}$ adjustment and concentration. The results obtained are shown in Table 8.
Table 8: Hair hydrolysate (final) characterization

\begin{tabular}{lc}
\hline \multicolumn{1}{c}{ Parameter } & Result \\
\hline Total solids, (\%) & $37 \%$ \\
Organic Matter, (\% dry based) & $58 \%$ \\
Mineral Matter, (\% dry based) & $42 \%$ \\
\hline
\end{tabular}

\section{Leather Retanning Trials}

The dried and stacked crust leather pieces obtained from each trial were evaluated for physical-mechanical tests according to ISO 3377:2002 for tear strength, and ISO 3379:1976 for ball burst test (to evaluate the grain cracking) whose results are shown in Table 9.

Table 9: Physical and mechanical tests

\begin{tabular}{cccc}
\hline $\begin{array}{c}\text { Retanning } \\
\text { Trial }\end{array}$ & $\begin{array}{c}\text { Tear Strength } \\
(\mathrm{N})\end{array}$ & $\begin{array}{c}\text { Lastometer test } \\
\text { Load } \\
(\mathrm{N})\end{array}$ & $\begin{array}{c}\text { Distension } \\
(\mathrm{mm})\end{array}$ \\
\hline 1 & 169 & 406.7 & 7.8 \\
2 & 176 & 371.9 & 7.3 \\
3 & 176 & 430.0 & 7.0 \\
4 & 209 & 328.7 & 7.0 \\
5 & 211 & 392.6 & 7.0 \\
6 & 212 & 415.3 & 7.3 \\
7 & 151 & 291.0 & 7.1 \\
8 & 146 & 260.4 & 6.8 \\
\hline
\end{tabular}

The results obtained, when compared with reference values generally accepted for footwear application: $200 \mathrm{~N}$ for load and $7 \mathrm{~mm}$ for distension in lastometer test and $120 \mathrm{~N}$ for tear strength, are good except for trial 8 where 
the distension is closed to 7 but slightly less.

The evaluation of the crust leather pieces obtained for softness and grain firmness are shown in Table 10.

Table 10: Summary of retanning trials

\begin{tabular}{ccc}
\hline Retanning trial & Softness* & Grain firmness** \\
\hline 1 & 3 & 3 \\
2 & 4 & 4 \\
3 & 4 & 4 \\
4 & 3 & 4 \\
5 & 3 & 4 \\
6 & 3 & 4 \\
7 & 3 & 4 \\
8 & 3 & 4 \\
\hline 1 = very hard; 5 = very soft &
\end{tabular}

** 1 = grain very loose; 5 = grain very firm

Table 10 shows that the leather behavior is similar to the standard regarding softness and better than standard regarding firmness.

\section{Leather Finishing Trials}

Analyzing the four finished samples, it can be concluded that the leather finished with hair hydrolysate becomes too sticky.

The results of the colour fastness to rubbing (50 cycles) test, performed in dry conditions, done accordingly to the ISO 11640, are displayed in Table 11.

Table 11: Colour Fastness to Rubbing

\begin{tabular}{cc}
\hline Sample & Grey Scale \\
\hline I & 5 \\
II & 3 \\
III & 5 \\
IV & $4 / 5$ \\
\hline
\end{tabular}

The results of colour fastness to rubbing show that the samples with the casein/albumin finishing have better performance.

\section{CONCLUSIONS}

The aim of this work was the study of bovine hair hydrolysate and sulfited lignins effect in leather retanning process.

Hair from bovine hide can be obtained from a hair-saving liming process and, after alkaline and thermal digestion, gives rise to a hydrolysate that can be used as a retanning agent for wet-blue leather. The synergic effect of sulfited lignins and hair hydrolysate on leather retanning was studied. It was shown that hair hydrolysate, sulfited lignins and its mixtures can be used as retanning agents with good results when compared with a dispersing agent and a synthetic tannin. Physical mechanical properties of leather were good, satisfying the minimum normally accepted for footwear, also leather characteristics as firmness and softness presented very good results.

The hair hydrolysate was further tested as finishing agent against casein. The results obtained showed that it is not a good alternative as finishing agent.

A validation of these results at a pilot scale with different kind of hides will be important.

\section{Acknowledgements}

The authors would like to acknowledge QREN Portuguese National Program and IAPMEI for the support of the Project INDIWHITE.

\section{REFERENCES}

1. Heidemann, E., Fundamentals of Leather Manufacture, Eduard Roether KG, 1993, pp. 180-193.

2. Sousa, F.M., Revista do Couro, 2006, 198, 95-101.

3. Tahiri, S., Guardia, M., J Am Leather Chem As, 2009, 104, 52-67.

4. Adzet, J.M., World Leather,1998, November, 33-36.

5. Cantera, C.S., Buljan, J., World Leather, 1997, November, 51-56.

6. Adzet, J.M., Química-Tecnica de Teneria, Romanya/Valls, 1985, pp. 257-261.

7. Crispim, A., Mota, M., J Soc Leath Tech Ch, 2003, 87, 203-207.

8. Bragança, I., Crispim, A., Sampaio, A., Ramalho, E., Crispim, F., Caetano, N.S., Silva, P.C., J Soc Leath Tech Ch, 2013, 97, 62-67.

9. Catalina, M., Celma, P., Cot, J., Manich, A., Marsal, A., J Am Leather Chem As, 2011, 106, 153-160.

10. Eaton, D. et al., Standard Methods of the Examination of Water and Wastewater, 1998.

(C) 2018 by the author(s). Published by INCDTPICPI, Bucharest, RO. This is an open access article distributed under the terms and conditions of the Creative Commons Attribution license (http:// creativecommons.org/licenses/by/4.0/). 